\title{
Hyperbaric oxygen therapy aggravates liver reperfusion injury in rats $^{1}$
}

\author{
Oxigenoterapia hiperbárica agrava lesão de reperfusão hepática em ratos
}

\author{
Cristiano Xavier LimaI, Marcelo Dias Sanches", João Baptista de Rezende Neto", Roberto Carlos de Oliveira e Silva"II,

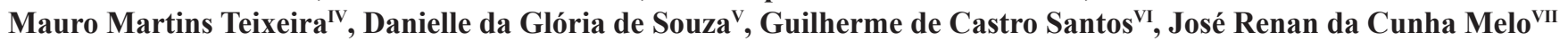 \\ ${ }^{\text {I }}$ MS, Fellow PhD degree, Department of Physiology, School of Science, Federal University of Minas Gerais (UFMG), Brazil. \\ II $\mathrm{PhD}$, Associate Professor, Department of Surgery, UFMG, Brazil. \\ III PhD, Volunteer Faculty, Department of Surgery, UFMG, Brazil. \\ Iv PhD, Full Professor, Department of Biochemistry and Immunology, School of Science, UFMG, Brazil. \\ ${ }^{v} \mathrm{PhD}$, Associate Professor, Department of Microbiology, School of Science, UFMG, Brazil. \\ ${ }^{v I}$ Resident of Surgery, UFMG, Brazil. \\ ${ }^{\text {VII }}$ PhD, Full Professor, Department of Surgery, UFMG, Brazil.
}

\begin{abstract}
Purpose: To evaluate the effects of hyperbaric oxygen (HO) therapy in the protection against liver ischemia/reperfusion injury. Methods: Thirty-two male Wistar rats were divided into four groups of eight animals each: group A - laparotomy and liver manipulation, group B - liver ischemia and reperfusion, group C - HO pretreatment for 60 min followed by liver ischemia and reperfusion, and group D - pretreatment with ambient air at 2.5 absolute atmospheres for 60 min followed by liver ischemia and reperfusion. Plasma was assayed for aspartate aminotransferase (AST), alanine aminotransferase (ALT) and lactate dehydrogenase (LDH). Intra-arterial blood pressure was monitored continuously. Myeloperoxidase activity in the liver and lung was assessed 30 min after reperfusion. Results: Plasma AST, ALT and LDH increased after reperfusion in all animals. Plasma ALT values and myeloperoxidase activity in the liver parenchyma were higher in HO-pretreated animals than in groups A, B and D. HO had a negative hemodynamic effect during liver reperfusion. Conclusion: Liver preconditioning with hyperbaric oxygen therapy aggravated liver ischemia/reperfusion injury in rats as demonstrated by plasma ALT and liver myeloperoxidase activity. Key words: Reperfusion Injury. Liver. Hyperbaric Oxygenation. Rats.
\end{abstract}

\section{RESUMO}

Objetivo: Avaliar os efeitos da oxigenoterapia hiperbárica $(\mathrm{OH})$ como método preventivo da lesão de isquemia e reperfusão (LIR) do fígado. Métodos: Trinta e dois ratos machos Wistar foram distribuídos em quatro grupos de oito animais cada: A laparotomia e manipulação hepática, $\mathrm{B}$ - isquemia e reperfusão hepática, $\mathrm{C}$ - pré-tratamento com $\mathrm{OH}$ por 60 minutos seguido de isquemia e reperfusão hepática e D - pré-tratamento com ar ambiente a 2,5 atmosferas absolutas por 60 minuto e isquemia e reperfusão hepática. Dosagens seriadas de AST, ALT e DHL foram realizadas. A pressão intra arterial foi monitorizada continuamente. O grau de infiltração leucocitária no fígado e pulmões foi inferido pela dosagem de mieloperoxidade tecidual. Resultados: O nível sérico de AST, ALT e DHL aumentou em todos animais. Os animais expostos a OH apresentaram níveis de ALT e infiltração leucocitária hepática maior que os demais. A OH apresentou efeitos hemodinâmicos negativos durante a reperfusão hepática. Conclusão: O pré-condicionamento hepático por oxigenoteraia hiperbárica agrava a lesão de isquemia e reperfusão hepática em ratos.

Descritores: Traumatismo por Reperfusão. Fígado. Oxigenação Hiperbárica. Ratos

${ }^{1}$ Research performed at Experimental Laboratory, Department of Surgery, Medicine Faculty, Federal University of Minas Gerais (UFMG), Brazil. 


\section{Introduction}

Liver ischemia-reperfusion injury (IRI) occurs in the case of temporary deprivation of blood flow to the liver (hepatectomy, liver transplant, hemorrhagic shock), and can cause from a mild increase in the serum level of liver enzymes to severe acute liver failure. The intensity of liver damage is directly related to the duration of ischemia and is the consequence of interactions between the depletion of adenosine triphosphate and the adhesion and activation of leukocytes, Kupffer cells and platelets in the liver sinusoids. Proteases, phospholipases, complement and reactive oxygen species also play a role ${ }^{1}$.

The beneficial effects of $\mathrm{HO}$ on the treatment of diseases associated with tissue ischemia have been well established ${ }^{2}$. However, its clinical application to the liver is recent and is restricted to isolated cases of diseases such as chronic viral hepatitis ${ }^{3}$, postoperative liver failure in cirrhotic patients ${ }^{4}$, post-liver transplant artery ischemia ${ }^{5}$, and acute fulminant hepatitis $^{6}$. Despite promising results in these situations, the small number of reported cases and the lack of controlled clinical studies do not permit conclusions so far. An experimental study has demonstrated the beneficial effect of postoperative HO in rats submitted to hepatic vein ligation, with the observation of a reduction in postoperative mortality and attenuation of histological alterations in the liver ${ }^{7}$.

The objective of the present study was to evaluate the effects of $\mathrm{HO}$ preconditioning on liver IRI in rats.

\section{Methods}

Thirty-two male Wistar rats (Rattus norvegicus albinos), weighing between 210 and $270 \mathrm{~g}$, from the animal house of Instituto de Ciências Biológicas, Universidade Federal de Minas Gerais, were used. The animals were kept at the Central Animal House of Faculdade de Medicina, Universidade Federal de Minas Gerais, and received balanced chow appropriate for rats (Purina, Campinas, SP) and drinking water ad libitum. The project was approved by the Ethics Committee on Animal Experimentation of Universidade Federal de Minas Gerais.

The 32 animals were divided into four groups of eight animals and each group was submitted to the following procedures:

- group A ( $\mathrm{n}=8$, control): laparotomy and manipulation of the hepatic pedicle;

- group $B(n=8)$ : laparotomy and occlusion of the vascular pedicle of the middle and left lateral lobe of the liver during 30 min, followed by reperfusion during $30 \mathrm{~min}$;

- group $\mathrm{C}(\mathrm{n}=8)$ : $\mathrm{HO}$ therapy at 2.5 absolute atmospheres (ATA) for $60 \mathrm{~min}$, laparotomy, and occlusion of the vascular pedicle of the middle and left lateral lobe of the liver during $30 \mathrm{~min}$, followed by reperfusion during $30 \mathrm{~min}$;

- group D $(n=8)$ : exposure to ambient air at 2.5 ATA for $60 \mathrm{~min}$, laparotomy, and occlusion of the vascular pedicle of the middle and left lateral lobe of the liver during $30 \mathrm{~min}$, followed by reperfusion during $30 \mathrm{~min}$.

\section{Hyperbaric treatment}

The hyperbaric treatment sessions were performed in an A 240 multiplace hyperbaric chamber (Seaway Diver Ind Met e Mont Ltda, Santa Rosa, RS, Brazil). Oxygen (100\%) (group C) or ambient air (group D) was used and the pressure of the chamber was maintained at 2.5 absolute ATA for $60 \mathrm{~min}$. Compression and decompression were performed gradually at $0.1 \mathrm{ATA} / \mathrm{min}$. The temperature inside the chamber was kept between $22^{\circ} \mathrm{C}$ and $26^{\circ} \mathrm{C}$.

\section{Surgical procedure}

The animals were anesthetized by intraperitoneal application of both $2 \%$ xylazine hydrochloride $(15 \mathrm{mg} / \mathrm{kg})$ and $5 \%$ ketamine hydrochloride $(90 \mathrm{mg} / \mathrm{kg})$. Submitted to orotracheal intubation and placed under ventilation (Harvard Ventilator Rodents, Cambridge, MA, USA) at a respiratory frequency of 60 breaths per minute and a tidal volume of $1.5 \mathrm{~mL} / 100 \mathrm{~g}$ body weight. Heating pads under the animals were used to maintain the rectal temperature between $36-37^{\circ} \mathrm{C}$.

The left carotid artery was dissected and cannulated with a PE 10 polypropylene catheter (Clay Adams, Becton Dickinson, Sparks, MD, USA) for the measurement of blood pressure and collection of blood samples during the surgical procedure. The right jugular vein was dissected and catheterized with a PE10 polypropylene catheter (Clay Adams) for infusion of $0.9 \% \mathrm{NaCl}$ solution.

The middle and left lateral lobes of the liver were then submitted to ischemia by occlusion of their pedicles with a vascular microclamp (Yasargil FE-751, Aesculap, Melsungen, Germany) for $30 \mathrm{~min}$, followed by reperfusion for $30 \mathrm{~min}$. At the end of the experiment, the middle and left lateral lobes of the liver and lower lobe of the right lung were excised and stored frozen at $-80^{\circ} \mathrm{C}$ for further mieloperoxidase (MPO) activity measurement.

Blood samples $(600 \mu \mathrm{L})$ were collected before the surgical procedure, after $30 \mathrm{~min}$ of ischemia and after $30 \mathrm{~min}$ of liver reperfusion for the measurement of plasma aspartate aminotransferase (AST), alanine aminotransferase (ALT) and lactate dehydrogenase (LDH).

\section{Pressure monitoring}

The catheter introduced into the left carotid artery was connected to a pressure transducer (Transducer Amplifier, Model PM 1000, DATAQ Instruments, Inc., Akron, OH, USA) coupled to a computer equipped with the WinDaq Pro Acquisition program, version 2.09 (DATAQ Instruments, Inc.), and intra-arterial pressure was monitored during the intraoperative period.

\section{Blood biochemical analysis}

Changes in blood parameters resulting from liver IR injury were evaluated by the measurement of serum AST, ALT and LDH using an optimized ultraviolet kinetic method. 
Quantification of neutrophil tissue infiltration by myeloperoxidase activity measurement

Tissue samples of the liver and lung weighing $100 \mathrm{mg}$ each were suspended in $2.0 \mathrm{~mL}\left(4^{\circ} \mathrm{C}\right)$ phosphate buffer $(0.1 \mathrm{M}$ $\mathrm{NaCl}, 0.02 \mathrm{M} \mathrm{NaPO}_{4}, 0.015 \mathrm{M}$ Na-EDTA, pH 4.7), vortex homogenized, and centrifuged at $4^{\circ} \mathrm{C}$ for $15 \mathrm{~min}$ at $10,000 \mathrm{~g}$. Pellets were then resuspended in $2 \mathrm{~mL}$ phosphate buffer $(0.05 \mathrm{M}$ $\mathrm{Na}_{3} \mathrm{PO}_{4}, 0.5 \%$ HETAB, $\mathrm{pH} 5.4$ ) at room temperature. The suspension was frozen and thawed three times and centrifuged at $4^{\circ} \mathrm{C}$ for $15 \mathrm{~min}$ at $10,000 \mathrm{~g}$. Supernatants were stored at $-20^{\circ} \mathrm{C}$ for the MPO assay.

For the assay, $25 \mu \mathrm{L}$ of 3,3'-5, 5'-tetramethylbenzidine (TMB; Sigma, St. Louis, MO, USA) dissolved in dimethyl sulfoxide (Merck, Darmstadt, Germany) at a final concentration of $1.6 \mathrm{mM}, 100 \mu \mathrm{L} \mathrm{H}_{2} \mathrm{O}_{2}$ dissolved in phosphate buffer $(0.05 \mathrm{M}$ $\mathrm{Na}_{3} \mathrm{PO}_{4}, 0.5 \%$ HETAB, $\mathrm{pH} 5.4$ ) at a final concentration of $0.003 \% \mathrm{v} / \mathrm{v}$, and $25 \mu \mathrm{L}$ of the tissue sample supernatant were used. The reaction was started at $37^{\circ} \mathrm{C}$ for $5 \mathrm{~min}$ in a 96-well microplate by adding the supernatant and TMB solution. Next, $100 \mu \mathrm{L} \mathrm{H}_{2} \mathrm{O}_{2}$ was added and the mixture was again incubated at $37^{\circ} \mathrm{C}$ for $5 \mathrm{~min}$. The reaction was stopped by the addition of $100 \mu \mathrm{L} 4 \mathrm{M} \mathrm{H}_{2} \mathrm{SO}_{4}$ and quantified at $450 \mathrm{~nm}$ in a spectrophotometer (E max, Molecular Devices Corporation, Chicago, IL,
USA). Neutrophil content was calculated from a standard curve based on MPO activity and is expressed as the relative number of neutrophils per mg wet tissue.

\section{Statistical analysis}

The following variables were analyzed: mean arterial pressure (MAP), AST, ALT, LDH and hepatic and pulmonary MPO activity. The GraphPad Prism program for Windows, version 3.00 (GraphPad Software, San Diego, CA, USA), was used for construction of the graphs and statistical analysis. A level of significance of $p=0.05$ was adopted.

\section{Results}

\section{Intra-arterial pressure}

Partial occlusion of the hepatic pedicle did not cause significant changes in mean intra-arterial pressure (MAP). A decline in MAP was observed during the first 5 min after liver reperfusion (Table 1). The decline in the MAP was prolonged by pretreatment with $\mathrm{HO}$ or hyperbaric ambient air throughout the time of reperfusion.

TABLE 1 - Mean arterial pressure $(\mathrm{mmHg})$ in animals during the surgical procedure

\begin{tabular}{cccccccccccc}
\hline GROUPS & \multicolumn{7}{c}{ Mean arterial pressure } \\
\hline & $\mathbf{1}$ & $\mathbf{2}$ & $\mathbf{3}$ & $\mathbf{4}$ & $\mathbf{5}$ & $\mathbf{6}$ & $\mathbf{7}$ \\
\hline A & $96.6 \pm 11.4$ & $93.1 \pm 5.0$ & $93.0 \pm 14.6$ & $99.6 \pm 22.2$ & $92.7 \pm 14.0$ & $89.5 \pm 13.0$ & $92.6 \pm 11.2$ & $94.8 \pm 9.3$ & $94.6 \pm 11.4$ \\
B & $106.8 \pm 15.4$ & $82.3 \pm 23.6$ & $90.9 \pm 26.5$ & $91.9 \pm 19.1$ & $85.1 \pm 19.7$ & $73.9 \pm 16.2 *$ & $77.7 \pm 20.1$ & $79.9 \pm 21.9$ & $78.0 \pm 28.3$ \\
C & $106.7 \pm 9.0$ & $100.8 \pm 11.1$ & $99.1 \pm 12.0$ & $97.3 \pm 18.3$ & $88.1 \pm 9.7$ & $73.8 \pm 6.1 *$ & $71.1 \pm 17.9 *$ & $71.1 \pm 5.9 *$ & $68.7 \pm 3.6 *$ \\
D & $109.4 \pm 17.9$ & $94.6 \pm 19.5$ & $93.1 \pm 16.5$ & $104.1 \pm 25.6$ & $87.4 \pm 13.2$ & $73.1 \pm 9.8^{*}$ & $70.1 \pm 9.2 *$ & $75.8 \pm 17.2 *$ & $70.9 \pm 7.2 *$ \\
\hline
\end{tabular}

Times: 1-before ischemia, 2-ischemia (5min), 3-ischemia (10min), 4-ischemia (20min), 5-ischemia (30min), 6-reperfusion (5min), 7-reperfusion (10 min), 8-reperfusion (20min), 9-reperfusion (30 min).

group A ( $\mathrm{n}=8$, control): laparotomy and manipulation of the liver pedicle;

group B (n=8): laparotomy and 30 min occlusion of the vascular liver pedicle, followed by reperfusion for $30 \mathrm{~min}$;

group C ( $\mathrm{n}=8)$ : HO therapy at 2.5 ATA for $60 \mathrm{~min}$, laparotomy, 30 min occlusion of the vascular liver pedicle, followed by reperfusion for 30 min;

group D ( $\mathrm{n}=8)$ : exposure to ambient air at 2.5 ATA for $60 \mathrm{~min}$, laparotomy, and 30 min occlusion of the vascular liver pedicle, followed by reperfusion for $30 \mathrm{~min}$.

Values are the mean \pm standard deviation.

$*(\mathrm{p}<0.05)$ compared to mean arterial pressure at time 1 .

\section{Transaminases}

Preconditioning with $\mathrm{HO}$ or hyperbaric ambient air alone did not cause significant differences in serum AST, ALT or LDH levels. The same was observed after 30 min of partial liver ischemia. After $30 \mathrm{~min}$ of liver reperfusion, a significant increase $(\mathrm{p}<0.05)$ in AST, ALT and LDH levels was observed in all groups submitted to liver I/R compared to group A (control). In comparison to the control group, the increase in serum ALT levels was significantly higher in animals submitted to preconditioning with $\mathrm{HO}$ than in the other groups $(\mathrm{p}<0.05)$ (Figures 1 to 3 ). 


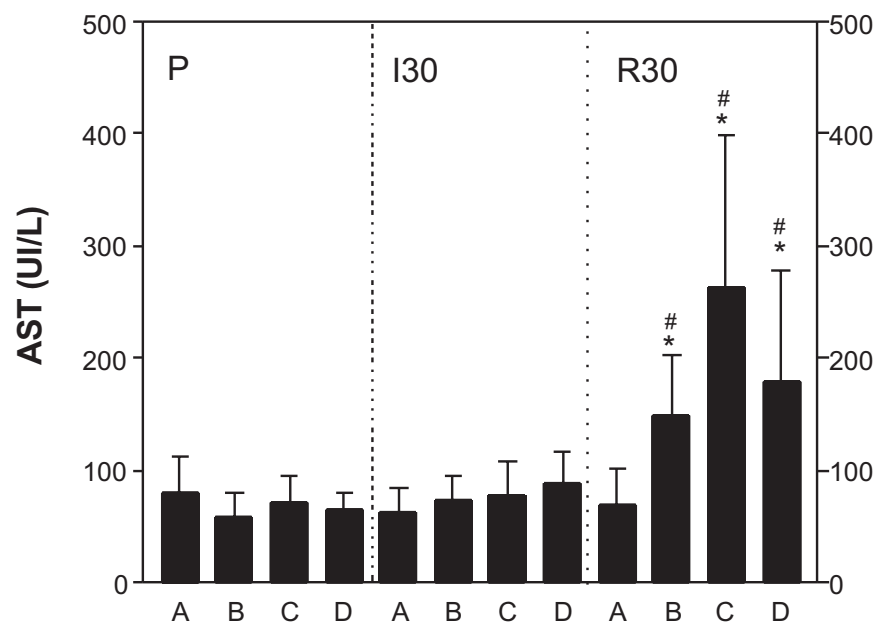

Groups

FIGURE 1 - Serum aspartate transferase (AST) level in animals during the surgical procedure

The columns represent the mean and the vertical bars indicate the standard deviation.

$\mathrm{P}$ - Before ischemia, I30 - 30 minutes of ischemia, R30 - 30 minutes of reperfusion

group $\mathrm{A}(\mathrm{n}=8$, control): laparotomy and manipulation of the liver pedicle; group $B(n=8)$ : laparotomy and 30 min occlusion of the vascular liver pedicle, followed by reperfusion for $30 \mathrm{~min}$;

group $\mathrm{C}(\mathrm{n}=8)$ : HO therapy at $2.5 \mathrm{ATA}$ for $60 \mathrm{~min}$, laparotomy, $30 \mathrm{~min}$ occlusion of the vascular liver pedicle, followed by reperfusion for $30 \mathrm{~min}$; group $\mathrm{D}(\mathrm{n}=8)$ : exposure to ambient air at $2.5 \mathrm{ATA}$ for $60 \mathrm{~min}$, laparotomy, and 30 min occlusion of the vascular liver pedicle, followed by reperfusion for 30 min.

$*(\mathrm{p}<0.05)$ AST R30 compared to AST P and AST I30.

\# ( $\mathrm{p}<0.05)$ AST R30 compared to AST R30 of group A .

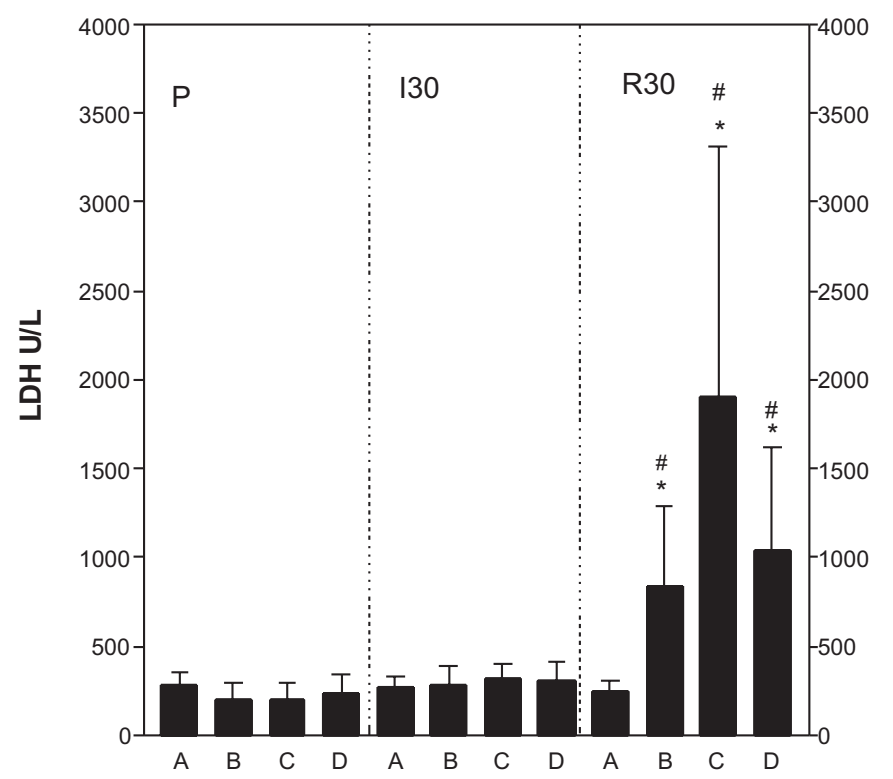

Groups

FIGURE 3 - Serum lactate dehydrogenase (LDH) level in animals during the surgical procedure

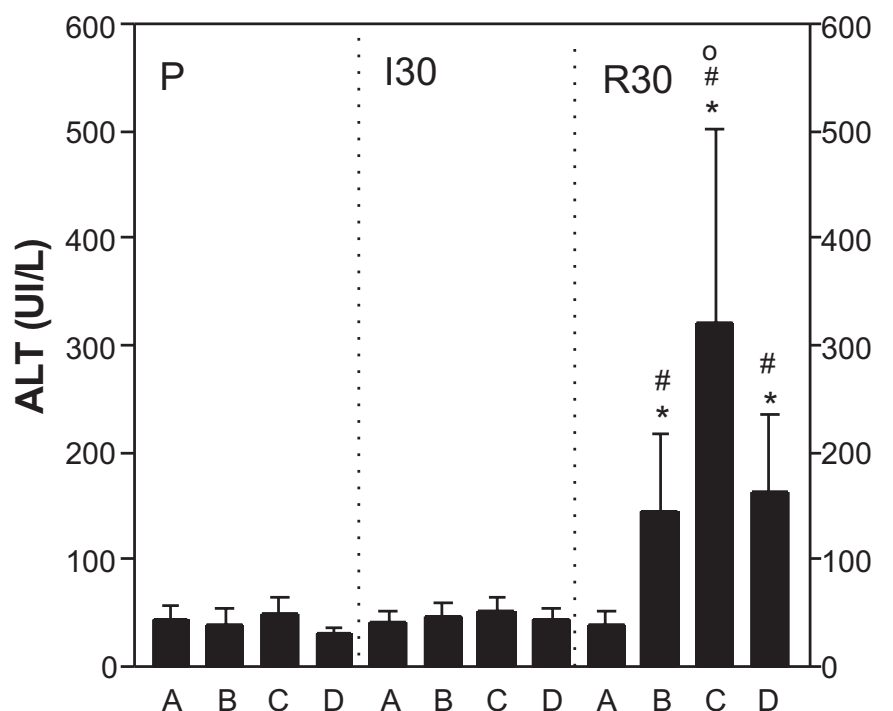

\section{Groups}

FIGURE 2 - Serum alanine transferase (ALT) level in animals during the surgical procedure

The columns represent the mean and the vertical bars indicate the standard deviation.

$\mathrm{P}$ - Before ischemia, I30 - 30 minutes of ischemia, R30 - 30 minutes of reperfusion

group $\mathrm{A}(\mathrm{n}=8$, control): laparotomy and manipulation of the liver pedicle; group $B(n=8)$ : laparotomy and 30 min occlusion of the vascular liver pedicle, followed by reperfusion for $30 \mathrm{~min}$;

group C ( $\mathrm{n}=8)$ : HO therapy at 2.5 ATA for $60 \mathrm{~min}$, laparotomy, $30 \mathrm{~min}$ occlusion of the vascular liver pedicle, followed by reperfusion for $30 \mathrm{~min}$;

group $\mathrm{D}(\mathrm{n}=8)$ : exposure to ambient air at 2.5 ATA for $60 \mathrm{~min}$, laparotomy, and 30 min occlusion of the vascular liver pedicle, followed by reperfusion for 30 $\min$.

$*(\mathrm{p}<0.05)$ ALT R30 compared to ALT P and ALT I30.

\# $(\mathrm{p}<0.05)$ ALT R30 compared to ALT R30 of group A.

$o(p<0.05)$ ALT R30 of group C compared to ALT R30 of groups B and D

The columns represent the mean and the vertical bars indicate the standard deviation.

$\mathrm{P}$ - Before ischemia, I30 - 30 minutes of ischemia, R30 - 30 minutes of reperfusion

group $\mathrm{A}(\mathrm{n}=8$, control): laparotomy and manipulation of the liver pedicle; group $B(n=8)$ : laparotomy and 30 min occlusion of the vascular liver pedicle, followed by reperfusion for $30 \mathrm{~min}$;

group C ( $\mathrm{n}=8)$ : HO therapy at 2.5 ATA for $60 \mathrm{~min}$, laparotomy, 30 min occlusion of the vascular liver pedicle, followed by reperfusion for $30 \mathrm{~min}$; group $\mathrm{D}(\mathrm{n}=8)$ : exposure to ambient air at 2.5 ATA for $60 \mathrm{~min}$, laparotomy, and $30 \mathrm{~min}$ occlusion of the vascular liver pedicle, followed by reperfusion for 30 min.

$*(p<0.05)$ LDH R30 compared to LDH P and LDH I30. \# $(\mathrm{p}<0.05)$ LDH R30 compared to LDH R30 of group A . 


\section{Tissue MPO activity}

Liver MPO activity was significantly higher in group C (animals submitted to HO pretreATAent, followed by liver I/ $\mathrm{R}$ ) when compared to the other groups (Figure 4). An increase in pulmonary MPO was observed in all animals submitted to liver I/R compared to the control group. This effect was significantly more marked in animals exposed to $100 \%$ oxygen (group C) or hyperbaric ambient air (group D). However, no significant differences were observed between groups $\mathrm{C}$ and D (Figure 5).

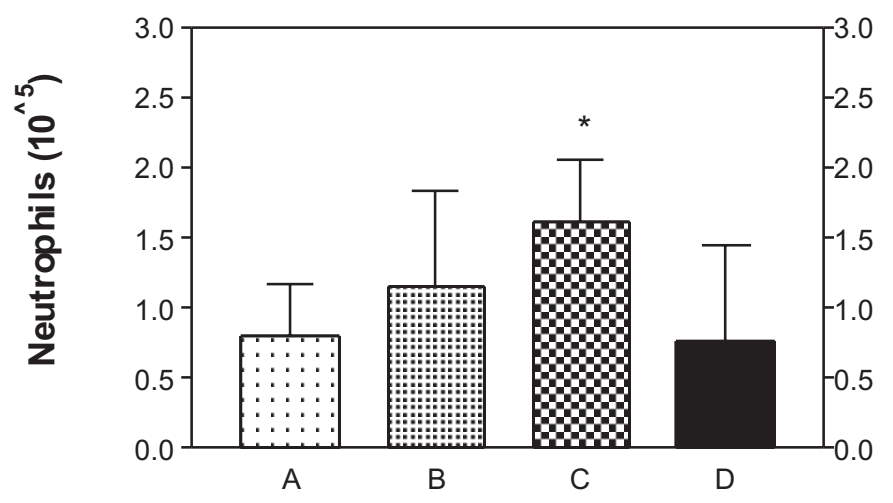

\section{Groups}

FIGURE 4 - Relative number of neutrophils/mg liver tissue after 30 min of segmental liver ischemia and $30 \mathrm{~min}$ of reperfusion

group A ( $\mathrm{n}=8$, control): laparotomy and manipulation of the liver pedicle; group $B(n=8)$ : laparotomy and 30 min occlusion of the vascular liver pedicle, followed by reperfusion for $30 \mathrm{~min}$;

group $\mathrm{C}(\mathrm{n}=8)$ : HO therapy at 2.5 ATA for $60 \mathrm{~min}$, laparotomy, $30 \mathrm{~min}$ occlusion of the vascular liver pedicle, followed by reperfusion for $30 \mathrm{~min}$; group D ( $\mathrm{n}=8)$ : exposure to ambient air at 2.5 ATA for $60 \mathrm{~min}$, laparotomy, and 30 min occlusion of the vascular liver pedicle, followed by reperfusion for 30 $\min$.

The columns represent the mean \pm standard deviation. $*(\mathrm{p}<0.05)$ compared to groups A, B and D.

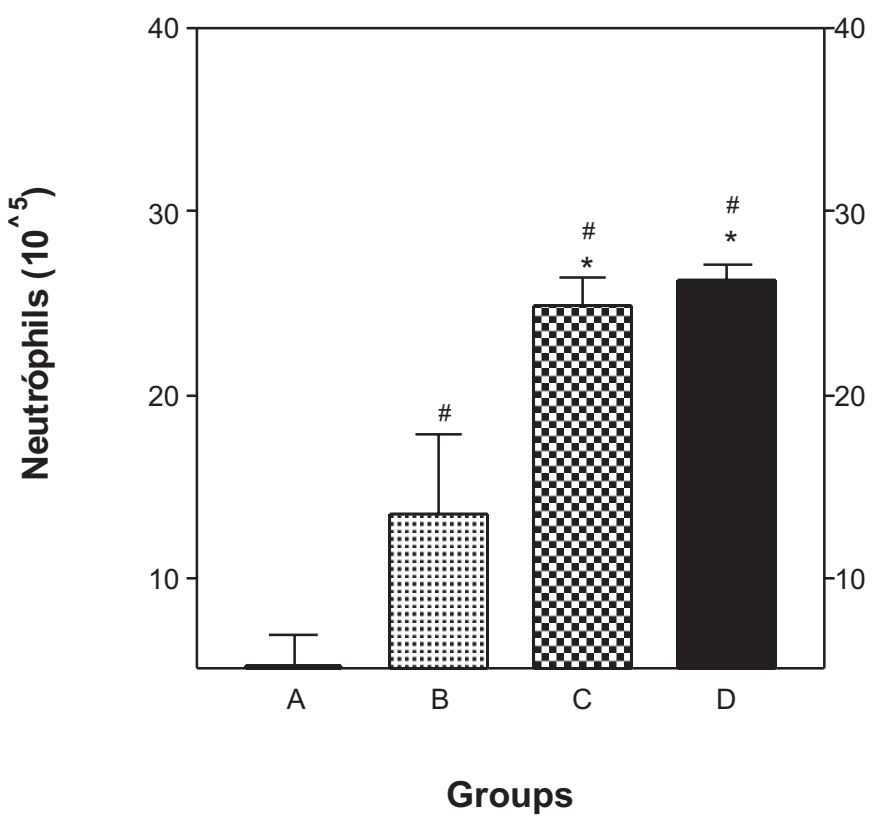

FIGURE 5 - Relative number of neutrophils/mg lung tissue after 30 min of segmental liver ischemia and $30 \mathrm{~min}$ of reperfusion

group A ( $\mathrm{n}=8$, control): laparotomy and manipulation of the liver pedicle; group $\mathrm{B}(\mathrm{n}=8)$ : laparotomy and $30 \mathrm{~min}$ occlusion of the vascular liver pedicle, followed by reperfusion for $30 \mathrm{~min}$;

group $\mathrm{C}(\mathrm{n}=8)$ : HO therapy at 2.5 ATA for $60 \mathrm{~min}$, laparotomy, $30 \mathrm{~min}$ occlusion of the vascular liver pedicle, followed by reperfusion for $30 \mathrm{~min}$; group D ( $\mathrm{n}=8)$ : exposure to ambient air at 2.5 ATA for $60 \mathrm{~min}$, laparotomy, and 30 min occlusion of the vascular liver pedicle, followed by reperfusion for 30 $\min$.

The columns represent the mean \pm standard deviation.

$*(\mathrm{p}<0.05)$ compared to groups A and B.

\# $(\mathrm{p}<0.05)$ compared to group A.

\section{Discussion}

During hepatectomy, the techniques used for the prevention and control of transoperative bleeding expose the liver to periods of ischemia. Alterations observed during the reperfusion period, which are mainly related to the duration of ischemia, include hepatic microcirculatory disorders, arterial hypotension, elevated serum aminotransferase and LDH concentrations, mitochondrial dysfunction, and lipoperoxidation. These alterations are the result of the complex interactions between adenosine triphosphate depletion, adhesion and activation of leukocytes, Kupffer cells and platelets in hepatic sinusoids, release of proteases and phospholipases, complement activation, and formation of reactive oxygen species ${ }^{1}$. Surgical and pharmacological methods for the prevention and treatment of liver IRI have been described ${ }^{2}$. The myocardium becomes resistant to the deleterious effects of $\mathrm{I} / \mathrm{R}$ when previously exposed to short periods of vascular occlusion led to the successful application of this technique, known as ischemic preconditioning, to liver resections and transplantation ${ }^{8}$. 
The biochemical and cellular effects of HO on IRI are still not completely understood. First, it was believed that HO may exacerbate injuries by increasing the oxygen supply to the organism, producing an increased number of free radicals. However, experimental studies in rats submitted to skin I/R have demonstrated the beneficial effects of HO during reperfusion ${ }^{9}$. HO decreases endothelial adhesion of neutrophils by reducing the expression of intercellular adhesion molecules on the surface of endothelial cells and may increase the tissue concentration of antioxidant enzymes such as myocardial catalase ${ }^{10}$.

The experimental application of HO to liver IRI has been described in two situations: as a preventive method before liver ischemia or reperfusion ${ }^{11,12}$, or as a postoperative therapeutic measure ${ }^{13}$. These studies indicate that the use of $\mathrm{HO}$ for short periods of time, causing cell oxidative stress, protects the liver against injuries associated with tissue reperfusion by a biochemical mechanism that is still unknown.

In the present study, HO was used as a preconditioning method in rats submitted to selective liver ischemia and reperfusion. The effects of $\mathrm{HO}$ on liver IRI were studied by measurement of serum AST, ALT and LDH, MAP, and the degree of leukocyte infiltration as demonstrated by hepatic and pulmonary MPO activity. Exposure of the animals to HO for $60 \mathrm{~min}$ did not cause any alteration in serum transaminase or LDH levels, changes commonly observed during surgical methods of ischemic preconditioning. One hypothesis for this finding is that, in contrast to other methods, the effect of liver preconditioning with $\mathrm{HO}$ is based on mild hepatocellular oxidative stress which ceases before the formation of AST and ALT ${ }^{12}$. However, there are no specific studies addressing this question.

This is the first study demonstrating the deleterious effects of HO preconditioning on liver IRI. Post-reperfusion serum ALT levels were significantly higher in animals submitted to HO therapy compared to the other groups. Previous studies in which $\mathrm{HO}$ was used as a preconditioning method reported no increase of serum AST or ALT concentration after I/R ${ }^{11,12}$. The present data also show no change in the serum level of these enzymes during the period of ischemia.

Changes in MAP after hepatic pedicle occlusion pedicle are expected since the interruption of hepatic blood flow causes splanchnic blood stasis and reduces venous return to the heart, with a consequent decrease in cardiac output. The return of blood flow to the ischemic portion of the liver induces the release of vasodilatory substances into the systemic circulation, reducing peripheral vascular resistance, with consequent arterial hypotension. In the present study, partial occlusion of the hepatic pedicle for $30 \mathrm{~min}$ was not associated with intraoperative death and did not result in any significant decline of MAP possibly because only part of liver flow was interrupted with no severe change in splanchnic venous drainage. A significant decrease in MAP was observed after liver reperfusion, which was rapidly reversed in animals without preconditioning but persistent in animals submitted to preconditioning with $\mathrm{HO}$ or hyperbaric ambient air

Kupffer cells play a central role in liver IRI because they produce inflammatory mediators such as TNF- $\alpha$ and IL-6, followed by transmigration of activated polymorphonuclear neu- trophils into the liver interstitium. The important presence of polymorphonuclear neutrophils in the pulmonary circulation renders the lung highly vulnerable to the cytotoxic action of inflammatory mediators and this organ was therefore studied in the present model of liver IRI ${ }^{14}$.

Hepatic MPO concentration after reperfusion was higher in the group of animals pretreated with $\mathrm{HO}$. This change was probably associated with $\mathrm{HO}$ since hyperbaric exposure alone (group D) did not provoke any increase in hepatic MPO concentration. Pulmonary MPO concentration was significantly higher in animals pretreated with $\mathrm{HO}$ or hyperbaric ambient air compared to the control group and to animals submitted only to liver I/R (group B). The last group, however, presented significantly higher MPO levels than the control group. These findings suggest that IR by itself causes the increase of MPO activity in liver and lung and that this increase is accentuated by HO pretreatment of the animals. In a review of the literature, we did not find other studies evaluating the role of $\mathrm{HO}$ preconditioning and pulmonary alterations resulting from liver IRI, although an experimental study on rats using $\mathrm{HO}$ in a muscle $\mathrm{I} / \mathrm{R}$ model has shown a reduction in the concentration of pulmonary leukocytes when $\mathrm{HO}$ was used ${ }^{15}$.

The present results are divergent from those reported in two other studies, in which HO preconditioning exerted a protective effect on liver $\mathrm{I} / \mathrm{R}^{10,11}$. However, these studies should be compared in view of the following observations. Differences in the duration of $\mathrm{I} / \mathrm{R}$ between studies led to the evaluation of different periods of the inflammatory response. Other investigations have emphasized an increase in the tissue level of enzymatic systems that protect against lipoperoxidation, such as catalase and superoxide dismutase, in animals submitted to cardiac preconditioning with $\mathrm{HO}^{10}$, which may also indicate a proinflammatory response.

\section{Conclusion}

The rats submitted to hyperbaric oxygen therapy before selective normothermic liver ischemia and reperfusion presented an increase in serum ALT concentration and hepatic and pulmonary myeloperoxidase concentration, as well as a decrease in mean arterial pressure, during the surgical procedure. These results suggest that liver preconditioning with hyperbaric oxygen therapy aggravates hepatocellular injury and leukocyte infiltration in the liver and lung immediately after ischemia and reperfusion of the liver.

\section{References}

1. Miranda LEC, Viaro F, Ceneviva R, Évora PRB. The experimental basis of hepatic ischemia-reperfusion injury: review. Acta Cir Bras. 2004;19(1):1-12.

2. Niinikoski JK. Clinical hyperbaric oxygen therapy, wound perfusion, and transcutaneous oximetry. World J Surg. 2004;28(3):307-11. 3. Liu W, Zhao W, Lu X, Zheng X, Luo C. Clinical pathological study of treatment of chronic hepatitis with hyperbaric oxygenation. Chin Med J. 2002;115:1153-7.

4. Nazyrov FG, Akilov KA, Ibadov RA, Asabaer ASH, Zainutdinov UI, Khafizov BB. Some pathogenetic aspects of developing liver fail- 
ure and preventing it in patients with liver cirrhosis after portosystemic shunting. Vestn Khir Im I I Grek. 2002;161:87-90.

5. Mazariegos GV, O'Took K, Mielos LA, Dvorchila I, Meza MP. Hyperbaric oxygen therapy for hepatic artery thrombosis after liver transplantation in children. Liver Transpl Surg. 1999;5:429-36.

6. Ponikvar R, Buturovic J, Cizman M, Mekjavic I, Kandus A, Premru V. Hyperbaric oxygenation, plasma exchange and hemodialysis for treATAent of acute liver failure in a 3-years-old child. Artif Organs. 1998;22:952-7.

7. Rosario RCV, Nunes TA, Silva RCO, Souza TKP. Hyperbaric oxygen therapy in rats submitted to hepatic veins ligation: mortality evaluation and histological study of liver and spleen. Acta Cir Bras. 2006;21(1):51-6.

8. Murry CE, Jennings RB, Reimer KA. Preconditioning with ischemia: a delay of lethal cell injury in ischemic myocardium. Circulation. 1986;74(5):1124-36.

9. Zamboni WA, Roth AC, Russell RC, Smoot EC. Effect of hyperbaric oxygen on reperfusion of ischemic axial skin flaps: a laser Doppler analysis. Ann Plast Surg. 1992;28(4):339-41.
10. Kim $\mathrm{CH}$, Choi H, Chun YS, Kim GT. Hyperbaric oxygenation pretreatment induces catalase and reduces infarct size in ischemic rat myocardium. Pflungers Arch. 2001;442(4):519-25.

11. Chen M, Chem HM, Ueng S, Shyr MH. Hyperbaric oxygen pretreatment attenuates hepatic reperfusion injury. Liver. 1998;18:110-6. 12. Yu SY, Chiu JH, Yang SD, Yu HY, Hsieh CC, Chen PJ, Lui WY, $\mathrm{Wu} \mathrm{CW}$. Preconditioned hyperbaric oxygenation protects the liver against ischemia/reperfusion injury in rats. J Surg Res. 2005;128:28-36. 13. Kihara K, Ueno S, Skoda M, Aikou T. Effects of hyperbaric oxygen exposure on experimental hepatic ischemia reperfusion injury: relationship between its timing and neutrophil sequestration. Liver Transpl. 2005;11(12):1574-80.

14. Rezende-Neto JB, Moore EE, Masuno T, Moore PK, Johnson JL, Sheppard FR, Cunha-Melo JR, Silliman CC. The abdominal compartment syndrome as a second insult during systemic neutrophil priming provokes multiple organ injury. Shock. 2003;20(4):303-8.

15. Zamboni WA, Wong HP, Stephenson LL. Effect of hyperbaric oxygen on neutrophil concentration and pulmonary sequestration in reperfusion injury. Arch Surg. 1996;131(7):756-60.

Conflict of interest: none Financial source: $\mathrm{CAPES} / \mathrm{CNPq}$

\section{Correspondence:}

Cristiano Xavier Lima

Rua Julia Nunes Guerra, 194/301

30380.400 Belo Horizonte - MG Brazil

Phone: (55 31)3295-1832

cxlima@globo.com

Received: January 16, 2008

Review: February 15, 2008

Accepted: March 20, 2008

\section{How to cite this article}

Lima CX, Sanches MD, Rezende Neto JB, Silva RCO, Teixeira MM, Souza DG, Santos GC, Melo JRC. Hyperbaric oxygen therapy aggravates liver reperfusion injury in rats. Acta Cir Bras. [serial on the Internet] 2008 July-Aug;23(4). Available from URL: http://www.scielo.br/acb 